\title{
SUNRANG TANAH SEBAGAI MAHAR UNTUK MENINGKATKAN INDENTITAS DIRI PEREMPUAN DALAM PERKAWINAN BUGIS MAKASSAR
}

\author{
Oleh: Nurlia \\ Dosen Universitas Negeri Makassar \\ Nurasiah \\ Mahasiswi Pascasarjana Mercu Buana Yogyakarta \\ E-mail : Sekalachsweet@yahoo.com
}

\begin{abstract}
Penelitian ini bertujuan untuk mengetahui bagaimana kedudukan perempuan yang menerima tanah sebagai mahar dalam perkawinan pada suku Bugis-Makassar, sejauh mana pemahaman perempuan tentang hak-hak atas tanah pemberian dalam perkawinan, tujuan pemberian mahar pada pihak perempuan menurut perspektif perempuan Bugis Makassar, mendeskrepsikan pemahaman perempuan mengenai pemberian tanah sebagai mahar dalam pernikahan adat Bugis-Makassar, serta mendeskrepsikan pemberian mahar sebagai identitas diri perempuan dalam perkawinan. Pengumpulan data dilakukan dengan metode penelitian Kualitatif dengan menggunakan wawancara dan observasi, artinya ada interaksi dengan orang yang telah diteliti, bagaimana pemahaman budanya, nilai-nilai yang dianutnya, motif dan sebagainya. Proses wawancara dilakukan terhadap 4 orang subjek dengan menggunakan pedoman wawancara yang memuat pokok-pokok pertanyaan yang ditujukan pada informan utama dan informan pendukung, pertanyaan bersifat berkembang, yaitu pertanyaan tidak hanya terkait dengan apa yang menjadi guide, akan tetapi juga mengikuti infoman sebagai cara mendapatkan data lebih luas. Dari hasil penelitian diperoleh bahwa pemahaman tanah sebagai mahar dan identitas diri pada perempuan dimulai ketika proses pelamaran dimulai, dan dilegalkan pada saat akad nikah karena tertulis dalam buku nikah, sunrang tanah yang diterimanya merupakan kesepakatan dari pihak laki-laki. Kepemilikan atas tanah pemberian sebagai mahar menjadi hak milik perempuan secara adat. Bahwa pemberian tanah sebagai mahar untuk melindungi perempuan setelah menikah, dalam artian tanah sebagai pelindung bagi posisi perempuan dalam keluarganya, dan juga secara psikologis pemberian tanah menjadi lambang harga diri (harkat dan martabat) untuk menghormati seorang perempuan baik sebelum pernikahan ataupun setelah pernikahan, dikarenakan pemberian sunrang tanah tersebut sebagai pelindung bagi pihak istri untuk mencari nafka ketika terjadi sesuatu yang tidak diinginkan. Selain itu juga sebagai pengingat bagi laki-laki agar tidak secara mudah meninggalkan istri dan anakanaknya tanpa tanggujawab.
\end{abstract}

Kata kunci: Sunrang tanah sebagai mahar, harga diri 


\section{LATAR BELAKANG}

Dalam Kehidupan manusia, tanah merupakan hal yang sangat penting. Sebagian besar penopang kehidupan manusia bersumber dan tergantung dari tanah, tanah sebagai sumber kehidupan dan menjadi tempat bermukim manusia. Selain itu tanah juga dinilai sebagai harta yang bersifat permanen karena memberikan suatu kemantapan untuk dicadangkan bagi kehidupan di masa datang. Fungsi tanah tidak hanya mempunyai nilai ekonomis seperti dijadikan hak gadai, hak tanggunan tetapi juga mempunyai fungsi sosial seperti dijadikan pasar, terminal dan lain-lain. Dengan demikian tanah tidak hanya memiliki arti tetapi juga fungsi yang sangat penting dalam kehidupan manusia (Budiman,1996).

Selain itu secara psikologis, tanah terkait dengan harkat dan martabat seseorang, hal ini terkait pada penghargaan laki-laki (pihak keluarga laki-laki) pada calon mempelai. Indonesia yang merupakan negara agraris hampir semua penduduknya hidup dari pertanian, demikian pula pada suku Bugis Makassar, salah satu mata pencahariannya adalah bertani. Adapun bentuk pertaniannya adalah bersawah, berladang dan berkebun.

Pada umumnya di daerah Bugis-Makassar masih menggunakan alat alat tradisional seperti bingkung atau cangkul dalam mengolah pertanian. Adapun petani yang menggunakan alat moderen umumnya digunakan oleh pengusaha petani/petani yang memiliki banyak tanah/usaha yang besar. Dalam keluarga, bertani dilakukan oleh semua anggota keluarga, biasanya pembagian pekerjaan yang berat seperti mencakul atau membawah hasil tani ke rumah masing-masing, sementara perempuan biasanya memberi pupuk, menanan, dan sebagainya. Oleh karena itu, dapat dikatakan bahwa tanah bukan sebagai pencitraan jenis kelamin tertentu, baik laki-laki maupun perempuan. Keduanya memiliki hak dan kewajiban dalam memiliki, mengelolah sebagai cara untuk mempertahankan hidup.

Allah SWT menciptakan manusia terdiri atas laki-laki dan perempuan, keduanya kemudian memiliki ketertarikan psikologis yang biasanya dikatakan cinta/perasaan keterkaitan untuk menjalin hubungan suami istri dalam bentuk 
pernikahan. Pernikahan dimaksudkan sebagai cara manusia dalam mempertahankan keturunannya, tidak hanya kebutuhan seks semata akan tetapi pernikahan juga bertujuan untuk mempertahankan keturunan.

Di Sulawesi Selatan khususnya dalam pernikahan suku Bugis-Makassar dalam sebuah pernikahan, terjadi penyerahan sesuatu dari pihak laki-laki kepada pihak perempuan, yaitu benda yang bergerak ataupun benda yang tidak bergerak. Benda bergerak seperti emas, uang paknai, ternak dan beras. Sementara benda yang tidak bergerak seperti tanah. Biasanya pemberian benda yang tidak bergerak berupa sebidang tanah atau sawah, pemberian tanah ini dapat sebagai mas kawin atau suku makassar menyebutnya Sunrang.

Sebagimana yang ditegaskan dalam al-Qur'an pada surat an-Nisa ;4 memerintahkan kepada calon suami untuk membayar mahar :

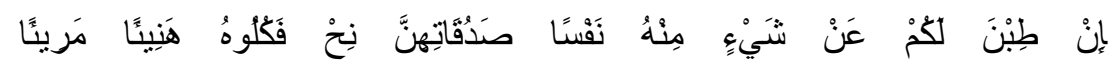
"Berikanlah mas kawin (mahar) kepada wanita yang kamu nikahi sebagai pemberian yang penuh kerelaan" (Q.S. an-Nisa:4). Suami berkewajiban menyerahkan mahar atau mas kawin kepada calon istrinya. Hal itu sebagai lambang kesiapan dan kesediaan suami untuk memberi nafkah lahir kepada istri dan anak-anaknya. Pada adat Bugis Makassar pemberian Sunrang yang diberikan oleh pihak laki-laki kepada pihak perempuan sudah menjadi hak milik perempuan sekalipun sudah tidak terikat dalam sebuah pernikahan.

Meskipun pada kenyataannya ada beberapa kasus yang berkaitan dengan pemberian Sunrang pada pihak perempuan menjadi sengketa, dimana tanah yang telah diberikan oleh mempelai pria ke pada istrinya biasanya juga diakui oleh orang tua perempuan. Hal itu menimbulkan ketidakjelasan ketika penyerahan sunrang tersebut, atau orang tua yang kurang memahami hukum adat yang mengatur tentang pemberian tanah yang ditujukan untuk putrinya sebagai identitas diri/hadiah dari keluarga suami untuk dijadikan modal usaha ketika mereka dipersatukan dalam ikatan pernikahan, meskipun secara sah tanah tersebut adalah milik istri akan tetapi suami biasanya juga ikut mengolah sebagai lahan mencari nafkah hidup. 
Selain itu, persoalan pemberian sunrang juga seringkali menjadi polemik sengketa antara keluarga pihak suami dan pihak isteri ketika terjadi perceraian atau perpisahan, suami dan keluarganya meminta kembali sunrang yang deberikan sebelumnya ketika terjadi perpisahan, akibatnya istri dan anak-anak harus rela melepas kembali pemberian tersebut dari pada berada pada konflik yang berkepanjangan. Padahal hal ini jelas sudah diatur dalam (Q.S an-Nisa:20-21)

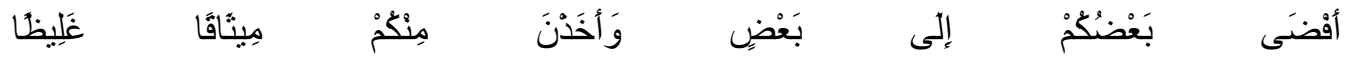

"Apakah kalian (hai para suami) akan mengambilnya kembali dengan jalan tuduhan yang dusta dan dengan menanggung dosa yang nyata? Bagaimana kamu akan mengambilnya kembali padahal sebagian kamu (suami dan istri) telah melapangkan (rahasianya / bercampur) dengan sebagian yang lain (istri atau suami) dan mereka (para istri) telah mengambil dari kamu perjanjin yang amat kokoh."

Ayat tersebut di atas jelas memberikan pemahaman bahwa sunrang tanah yang dijadikan sebagai mahar oleh laki-laki pada istri menjadi hak miliki istri, suami atau siapapun tidak memiliki hak atas kepemilikan Sunrang tanah tersebut, baik dalam kondisi masih bersama ataupun telah berpisah.

\section{TUJUAN PENELITIAN}

Sebagai cara untuk mengetahui hak-hak perempuan dalam pemberian tanah sebagai mahar, mengetahui bagaimana kedudukan perempuan yang menerima tanah sebagai mahar dalam perkawinan pada suku Bugis-Makassar, sejauh mana pemahaman perempuan tentang hak-hak atas tanah pemberian dalam perkawinan, tujuan pemberian mahar pada pihak perempuan menurut perspektif perempuan Bugis Makassar, mendeskrepsikan pemahaman perempuan mengenai pemberian tanah sebagai mahar dalam pernikahan adat Bugis-Makassar, serta mendeskrepsikan pemberian mahar sebagai identitas diri perempuan dalam perkawinan

\section{A. KERANGKA TEORI}


Budaya patriarki dalam sistem kekerabatan masyarakat suku Bugis Makassar masih sangat kental. Patriarki secara harfiah adalah menempatkan laki-laki atau ayah sebagai penguasa. Hal ini yang kemudian menjelaskan warnah dalam suatu masyarakat bahwa kaum laki-laki berkuasa atas kaum perempuan dan anak-anak. Dalam budaya patriarki ini kaum laki-laki diposisikan sebagai pihak yang superior kepada perempuan dalam berbagai sektor kehidupan. Laki-laki lebih banyak diakui di ranah puplik dan diberikan kesempatan dalam berkarya lebih luas dari pada kaum perempuan, meskipu.

Saat ini walaupun gerakan jender semakin berkembang akan tetapi terlihat bahwa kekuasan laki-laki masih sangat dominan atas perempuan. Sistem kekerabatan atau keluarga dalam kehidupan masyarakat suku Bugis Makasasar merupakan satu unit pandangan adat. Pada suku bugis makassar hubungan perseorangan biasanya dikaitkan dengan kekerabatan. Pertama konsep biologis yaitu : hubungan karena keturunan, kedua : berdasarkan hubungan sosial, sehingga dapat diaktakan bahwa kekerabatan merupakan bentuk hubungan dari ikatan sosial yang terdapat dalam masyarakat. Kekerabatan ini begitu penting dalam proses memperhangat hubungan sosial dikalangan Bugis Makassar, orang Bugis Makassar sangat senang memakai Saribattang (saudaraku), dalam memanggil nama seseorang, meskipun saudara yang dimaksudkan bukan saudara kandung tapi orang lain yang tidak memiliki hubungan keluarga.

Secara kekeluargaan masyarakat Bugis-Makassar hidup dalam satu rumah tangga yang rukun, dalam keluaga ini bukan hanya terdapat keluarga inti akan tetapi ada salah satu mertua dari pasangan suami istri mereka, ponakan ataupun sepupu dari pasangan suami istri, saudara jauh/sepupu dua kali yang belum dapat berdiri sendir secara ekonomi. Kesemuanya ini hidup dalam satu atap dengan kepala rumah tangga/yang memikul tanggungjawab adalah pasangan suami istri tersebut, baik kebutuhan sehari-hari maupun kebutuhan lainnya. Situasi kekerabatan yang seperti ini hampir dijumapi pada setiap rumah tangga pada Suku Makassar. Hal ini juga didasari oleh semboyang Bugis-Makassar yang dikenal dengan "siri" dan "passe" yang diyakini sebagai perekat terjalinnya persaudaraan yang kokoh, diimplementasikan pada kesamaan nasib 
ketika melihat saudara lainnya dalam situasi tidak menguntungkan maka lahirlah "pacce" (pacce ati) yaitu perasaan sakit yang muncul dalam hati melihat kondisi tersebut, maka muncullah empati yang didasari oleh perasaan masiri "malu" sebagai satu keluarga yang saling membantu, ketika melihat salah satu kerabat dalam keadaan membutuhkan pertolongan.

Sistem kekerabatan dalam adat Bugis-Makassar bersifat parental atau adaya keturunan ayah dan ibu. Menurut Ihromi (2000) ada keluwesan pemahaman dalam arti individu lebih berkesempatan memilih kerabat yang mana yang dipilihnya menjadi seseorang yang dijadikannya teman dalam hubungan sosial. Sehingga dapat disipulkan bahwa patriarki secara umum sudah menjadi ciri bagi suku Bugis-Makassar. Ini dapat dilihat dari tanggungjawab seorang laki-laki terutama anak sulung/anak pertama yang merupakan benteng pertama dalam keluarga yang menjaga "siri” (kehormatan) keluaga dalam masyarakat. Anak laki-laki memiliki hak kontrol dalam keluarga, meskipun anak tesebut sudah memiliki keluaga sendiri akan tetapi tanggujawab menjaga "siri” keluarga tetap melekat secara kuat dalam diriya.

Pendapat di atas diperkuat oleh Chabot (1984) yang menjelaskan bahwa ayah memegang kekuasaan besar terhadap anak laki-lakinya, anak laki-laki harus selalu mendengarkan perkataan dari seorang ayah, dan begitupun seorang adik perempuan harus selalu mendegarkan perkataan kakak laki-lakinya.

Dari uraian ini dapat dilihat bahwa budaya patriarki dalam kehidupan Bugis-Makassar menjadi adat yang sudah sangat melekat pada kehidupan Bugis Makassar. Peran dan status domestik perempuan Bugis-Makassar sebagai isteri adalah pedamping dan pelengkap suami. Sedangkan perang perempuan diidentikkan dengan melahirkan anak, mengurus dan mendampingi suami, serta bertanggujawab atas pekerjaan rumahtangga. Namun lebih banyak perempuan yang tidak menyadari situasi ini, apalagi dibandingkan dengan mereka yang berani memperjuangkan haknya (Erlina, 2000).

Sehingga dalam hal ini pemberdayaan perempuan sangatlah penting. Lebih lanjut dijelaskan oleh (Erlina, 2000) bahwa dalam pemberdayaan perempuan dibagi menjadi tiga macam yaitu pertama : pemberdayaan yang 
bersifat holistik karena mencakup pemberdayaan dalam arti ekonomi sosial budaya, politik dan psikologi. Kedua: diarahkan pada penanggulangan hambatan struktural dan terwujudnya kesejajaran perempuan dan laki-laki. Ketiga: dilaksanakan bersama-sama pemberdayaan perempuan dan pemberdayaan masyarakat pada umumnya.

Meskipun pemberdayaan perempuan telah dilakukan secara luas, namun masih banyak perempuan golongan mampu belum memiliki derajat kemandirian psikologi yang tinggi, seperti tingkat ketergantungan yang tinggi pada suami dan keluarga yang mudah jatuh dan mengalami depresi ketika dihadapkan pada realitas yang menuntut kemandirannya baik itu dalam kehidupan keseharian sosial maupun dalam pernikahan. Disaping itu, masih banyak perempuan yang tidak menguasai penuh atas pendapatan yang diperolehnya, demikian pula pada tingkat pendidikan yang diraih perempuan belum mampu mebawanya ketingkat kemadirian dalam arti melepaskan diriya dari kaidah sosial.

Konsep kepemiilikan tanah yang diberikan ke pada perempuan dalam perkawinan, berdasarkan pengertian pemilik tanah menurut konsep kebudayaan suku Bugis-Makassar, maka asal-usuk kepemilikan tanah sebagai mahar tersebut merupakan pemberian atau hadiah. Asal usul pembelian ini berkaitan erat dengan kebiasaan pada waktu tertentu memberikan areal tanah tersebut, misalnya pemberian sebagai mahar kepada pihak perempuan yang berari bahwa tanah tersebut murupakan hak milik perempuan. Setelah tanah tersebut menjadi milik perempuan maka tanah itu akan menjadi tanggujawab si pemilik tanah, bukan lagi dikuasi oleh suami/keluarga suami/keluarga istri tanpa persetujuan istri.

Pemberian mahar dalam bentuk tanah pada adat Bugis-Makassar, merupakan syarat dalam melaksanakan pernikahan. Menurut Koentjaraningrat (1980) ada beberapa istilah atas mahar tersebut salah satunya diaktakan sebagai mas kawin yang bertujuan untuk mengganti kerugian. Oleh Goode (1991) juga mengatakan bahwa mas kawin adalah sejumlah uang atau hak milik yang dibawah laki-laki pada waktu menikah. Dalam suatu kelompok, apabila 
seorang gadis dalam suatu kelompok tersebut kawin/menikah maka kelompok tersebut akan mengalami kerugian dengan hilangnya salah satu tenaga kerja, olehnya itu mas kawin sebagai penggantinya. Di dalam islam pun diatur bahwa mahar merupakan salah satu syarat dan rukun islam dalam pernikahan yang berupa tanah, pada adat suku Bugis-Makassar tidak hanya membayar mahar sebagai pengganti akan tetapi biasanya ditamabahkan dengan barang-barang lainnya.

Seperti yang telah dijelaskan di atas bahwa pemberian mahar tersebut bertujuan sebagai pengganti ke pada pihak perempuan dengan hilangnya anggota keluarganya, akan tetapi hak kepemilikan tanah tersebut dalam adat suku Bugis-Makassar mejadi hak milik perempuan, dan biasanya juga dikelolah oleh pihak perempuan dan suaminya. Meskipun masih banyak pertentangan atas kepemilkan tanah tesebut apakah kemudian menjadi hak milik keluarga dalam hal ini orang tua ataukah hak milik anak yang dipinang. Akan tetapi hukum adat mengatur bahwa kepemilkan tanah tersebut kembali pada tujuan pemberian tanah sebagai mahar/hadiah kepada sang istri dari calon suami sebagai bukti tanggungjawab suami ke pada istri, dan juga sebagai penghargaan harkat dan martabat bahwa seorang istri memiliki identitas diri (kehormatan) sebagai perempuan yang akan dilepaskan oleh orang tuanya untuk membentuk keluaga baru dan memilik hadiah tanah sebagai tempat tujuannya setelah menikah.

Biasanya seorang ayah akan melepas anaknya dengan tenang ketika mengetahui bahwa anaknya terjamin dalam rohani maupun jasmani, selain itu pemberian mahar tersebut bukan sekedar sebagai syarat sah pernikahan akan tetapi secara psikologis sebagai alat pemersatu bagi suami istri dimana suami setelah menikahi seorang istri akan berfikir beberapa kali untuk meninggalkan isteriya atau menceraikannya karena akan mengalami kerugian. Jadi boleh dikatakan bahwa secara psikologis tanah sebagai alat pengikat atau tanggujawab yang mempererat hubungan suami ke isteri dan anak-anaknya. 


\section{METODOLOGI PENELITIAN}

\section{A. Pendekatan Penelitian Observasi dan Wawancara}

Pengumpulan data dilakukan dengan metode penelitian kualitatif dengan menggunakan pendekatan studi kasus, yang berarti adanya interaksi dengan orang yang telah diteliti, bagaimana peahaman budanya, nilai-nilai yang dianutnya, motif dan sebagainya, alasan peneliti menggunakan studi kasus adalah karena terkendala waktu, dan berkaitan dengan kasus yang memang sedang terjadi saat ini dilihat sebagai fenomena yang terjadi pada adat BugisMakassar

Proses wawancara yang dilakukan dengan wawancara menggunakan pedoman wawancara yang memuat pokok-pokok pertanyaan yang ditujukan pada informan utama dan informan pendukung, pertanyaan bersifat berkembang, yaitu pertanyaan tidak hanya terkit dengan apa yang menjadi guide, akan tetapi juga mengikuti infoman sebagai cara mendapatkan data lebih luas.

Proses wawancara :

- Pembukaan dengan menjelaskan maksud dan tujuan wawancara.

- Pertanyaan bersifta ringat pada awal-awal wawancara

- Membicarakan pokok-pokok penelitian

- Menghubungkan informasi yang telah didapatkan dengan informasi lain

- Melakukan pertemuan intens dan terlibat dalam diskusi yang berkisar dengan pokok penelitian.

\section{B. Lokasi}

Penelitian ini mengambil informasi pada dua latar belakang suku/adat yang ada di Sulawesi Selatan, yaitu suku Bugis-Makassar. Yang berasal dari dari 
Kabupaten Gowa dan Kabupaten Soppeng. Gowa sebagai tempat penelitian selain dilatar belakangi karena kabupaten Gowa mayoritas adalah suku Makassar dan kabupaten Soppeng adalah mayoritas suku Bugis.

\begin{abstract}
ANALISIS MASALAH
Perempuan selalu dalam posisi tawar yang rendah, terkadang tidak memperoleh akses dalam pengambilan keputusan, serta tidak memperoleh kesempatan dalam beraktualisasi (Wijaya, 1993). Hal ini merupakan fakta kehidupan sosial saat ini, yang kemudian membuat banyak kaum akademisi manaruh perhatian berkaitan dengan masalah perempuan untuk mencoba mengubah kultur dan struktur sosial yang berlaku. Hal ini bertujuan untuk mengangkat pengalaman dan pengetahuan perempuan dalam kehidupan bermasyarakat. Selain itu sebagai dasar bagi perempuan untuk bagkit dari dikotomi-dikotomi opini yang menghargainya hanya sebagai barang dibeli, akan tetapi hal ini akan menjadi citra (harga diri) yang tinggi menjadi seorang perempuan. Selain itu penelitian ini juga untuk mengungkap pemahaman perempuan atas kepemilikan Tanah sebagi mahar yang diterimanya pada saat menikah. Atau lebih pada hak-hak perempuan atas tanah pemberian tersebut serta tujuan pemberian tanah sebagai mahar.
\end{abstract}

\title{
HASIL PENELITTIAN
}

\section{a. Proses perkawinan Bugis Makassar}

Adat istiadat pada kalangan Bugis-Makasar sangatlah dijunjung tinggi, meskipun beberapa perubahan sosial ataupun politik terjadi akan tetapi adat yang mereka yakini tetap semakin kokoh, hal ini terlihat dari beberapa adat tradisonal yang masih dipakai hingga sekarang dalam proses pernikahan. Hal ini dikarenakan adat bukan hanya sebagai kebiasaan dalam suku BugisMakassar akan tetapi adat merupakan suatu nilai budaya pada setiap budaya (Rahim 1992).

Pernikahan dalam Adat Bugis-Makassar merupakan acara yang sakral bagi keluarga besar kedua mempelai, hal itu karena terjadi proses pelepasan anak masing-masing untuk membentuk keluarga baru. Dalam acara sebuah 
pernikahan dianggap sebagai momentum silaturrahmi keluaga besar, berkumpul dengan sanak saudara yang jauh melepas rindu diantara mereka. Pernikahan akan disambut sangat meriah oleh masyarakat Bugis-Makassar dengan melakukan pesta sebagai lambang kepuasan bagi orang tua. Bahwa Ia, telah berhasil menikahkan anaknya. Proses pernikahan ini terjadi dalam beberapa tahap yaitu :

1. Peminangan (Accino rorong" dalam adat Makassar", Mappese"pese" dalam adat Bugis”. Ini sebagai awal bagi keluarga laki-laki untuk mengirim perwakilan keluarga menemui pihak keluarga perempuan. Proses awal ini sebagai ajang silaturrahim atau proses berkenalan dengan keluarga besar perempuan.

2. "Ma'manu-manu” dalam adat Bugis dan dalam adat Makassar dikenal dengan kata “a'jangang-jangang”. Hal ini di lakukan dari pihak laki-laki ke pada pihak perempuan untuk mengetahui apakah pihak perempuan sudah dilamar oleh orang lain atau belum,

3. “Assuro". Proses meminang

4. "Тарри kana" yaitu proses membicarakan uang "pa'nai" (mahar) dan sunrang tanah yang harus bepenuhi oleh pihak laki-laki pada pihak perempuan. Pembicaraan ini dilibatkan semua keluaga besar perempuan dan diwakili oleh utusan laki-laki yang datang pada pihak perempuan.

5. “Mappa'nesse” Bugis, "Appakajarre” Makassar. Tahap pengukuhan pembicaraan yang telah dilakukan sebelumnya, dengan membawakan kuekue tradisional dan beberapa hal yang berkitan dalam acara tersebut.

6. "Ma'pacci" yaitu proses pensucin dengan melakukan ritual-ritual lainya, biasaya acara ini dilakukan semalaman oleh kaum bangsawan, akan tetapi acara ini dilakukan cukup sederhana bagi kalangan biasa.

7. Simorong, yaitu proses mengantar laki-laki ke rumah calon isterinya oleh keluarga besarnya dengan membawa syarat-syarat yang menjadi adat.

8. Akad Nikah, yaitu proses pernikahan yaitu diadakannya Ijab Qobul antara kedua belapihak. 
9. “Tudang” dan "A'gau", yaitu proses resepsi dimana mempelai duduk dengan memakai pakaian menikah dan duduk bersnding di pelaminan didampingi oleh keluarga masing-masing, sekaligus proses menerima tamu, di rumah kedua mempelai secara bergantian.

10. "Mapparola-Nilekka” yaitu : datangnya utusan laki-laki untuk menjemput pihak wanita ke rumah mempelai laki-laki dan mempelai perempuan disambut dengan memberikan sesuatu dari mertua ketika memasuki halaman rumah.

\section{b. Pemahaman perempuan atas tanah yang dijadikan mahar dari pihak laki-} laki.

Dari proses wawancara dan observasi yang dilakukan maka dapat dijelaskan bahwa :

- Proses pemahaman ini dimulai pada tahap tappu kana” yaitu tahapan proses pernikahan yang telah di bahas di Atas. Pada tahap ini dibicarakanlah proses pemberian tanah dari pihak laki-laki ke pada pihak perempuan yang diwakili oleh orang tua wanita. Pada saat itu wanita mengetahui bahwa ia diberikan sunrang dengan sebidang tanah/sawah, oleh calon suaminya.

- Sunrang tanah diucapkan saat akad nikah, peberian tanah tersebut diucapkan laki-laki saat akad nikah, sehingga proses ini juga diketahui oleh perempuan bahwa ia diberikan tanah oleh calon suaminya.

- Sunrang tanah tersebut tertulis dalam buku nikah, hal ini juga sebagai penegasan pemberian sehingga dituliskan di dalam buku nikah

Jadi dapat disimpulkan bahwa pemberian tanah dari pihak laki-laki telah diketahui oleh pihak perempuan pada saat proses lamaran berlangsung, dan setelah menikah tanah tersebut menjadi hak perempuan seutuhnya. Namun meskipun demikian setelah pernikahan biasanya pihak perempuan tidak dengan serta merta mengakui bahwa tanah tersebut miliknya, akan tetapi membutuhkan proses dimana suami atau pihak keluarga untuk memberikan secara langsung, karena dalam suku Bugis-Makassar apabila perempuan bertindak secara langsung akan dikatakan sebagai orang yang Tidak memiliki "Siri" malu sebagai isteri. Dari hasil wawancara mengungkapkan 
bahwa seringnya komunikasi yang tidak berjalan dengan baik antara suami isteri terkait sunrang yang telah diberikan pada saat pernikahan seringkali menjadi masalah setelah pernikahan. Orang tua dan suami tidak pernah mengungkapkan akan tanah tersebut setelah pernikahan dalam situasi formil ataupun kekeluargaan karena kebanyakan orang tua menganggap sunrang tersebut hanya sebagai simbolik semata, sehingga sebagai orangtua mereka tidak memiliki kewajian untuk menegaskannya secara formal, akibatnya pihak istri tidak memiliki hak untuk mengolah dan memilikinya.

\section{c. Tanah sebagai penegasan identitas diri bagi kaum perempuan Bugis-} Makassar.

Tanah sebagai salah satu pusat kehidupan manusia, karena sumber kehidupan manusia berasal dari tanah, terutama oleh para petani BugisMakassar. Dari hasil wawancara juga terungkap bahwa sebagian besar penduduk Bugis-Makassar bermata pencaharian sebagai petani sehingga tanah menjadi tempat untuk menopang hidup, tanah juga sebagai lambang status sosial seseorang. Artinya semakin banyak tanah miliknya semakin terpandang, sebagai penegasan identitas diri bahwa pemberian tanah ke pada perempuan bukan simbolik sebagai syarat Sah-nya sebuah pernikahan, akan tetapi dari sisi psikologis dapat menempatan posisi perempuan untuk dihormati secara harkat dan martabat sehingga harga diri seorang perempuan tetap dihormati. Selain itu juga sebagai sebagai ikatan tanggujawab suami untuk memberikan pamentegang (tempat berdiri) secara ekonomi pada istrinya kelak dan juga dapat dimanfaatkan sebagai mata pencaharian bagi suami istri setelah mereka menikah.

Selain itu juga terungkap bahwa pemberian sunrang tanah sebagai tanda bahwa wanita memiliki harga atau nilai psikologis yang tinggi. Pemberian sunrang tanah sebagai bukti bahwa laki-laki yang ingin menikah telah memperlihatkan bahwa dirinya telah memiliki keberanian dan tanggujawab untuk menyediakan lahan nafkah untuk istri dan anaknya kelak. Hal itu menunjukkan betapa wanita Bugis Makassar dihargai kedudukannya. Dengan demikian suami tidak akan mudah melakukan perkawinan lalu bercerai atau 
berselingkuh karena ada konsekuensi logis baik materi maupun psikologis yang harus ditanggung oleh pihak laki-laki.

Oleh karena itu, dapat dikatakan bahwa pemberian tanah ini sebagai pelekat dan identitas perempuan untuk mempertahankan dirinya dalam sebuah ikatan pernikahan.

\section{KESIMPULAN}

Tanah sebagai mahar untuk mempertahankan identitas diri perempuan, merupakan cara dalam melindungi hak hidup perempuan yang dinafkahi oleh suaminya. Hal ini secara umum bertujuan sebagai pegangan bagi perempuan melakukan modal usaha sehingga dapat membantu siaminya dalam hal ekonomi, dan juga merupak pegangan ketika suatu waktu suaminya menceraikannya, sehingga perempuan tersebut memiliki hak untuk melajutkan kehidupanya dan menafkahi dirinya secara halal.

Proses inilah yang kemudian terkait dengan harga diri/identitas diri perempuan Bugis Makassar, dimana kedudukan seorang perempuan dalam keluarga memiliki kehormatan yang tinggi, dan sebagai orang tua dari perempuan yang akan melepas anaknya untuk menikah akan tenang menyerahkan putrinnya.

Pemahaman tanah sebagai mahar dan identitas diri pada perempuan dimulai ketika proses pelamaran dimulai, dan dilegalkan pada saat akad nikah karena tertulis dalam buku nikah, tanah yang diterimanya merupakan kesepakatan dari pihak laki-laki. Kepemilikan atas tanah pemberian sebagai mahar menjadi hak milik perempuan secara adat, meskipun secara hukum dapat menjadi masalah ketika pemberian tersebut tidak dilengkapi dengan sertifikat dan lainnya.

Masalah ini terjadi karena posisi perempuan yang lemah, sehingga yang terjadi biasanya adalah ketika tanah tersebut tidak jadi diberikan maka pihak perempuan tidak menuntutnya karena ada perasaan malu menuntut pada keluarga suaminya karena tidak adanya legalitas hak perempuan di mata 
hukum, hal dikarenakan tidak adanya aturan secara tegas dalam adat MakassarBugis yang mengatur sunrang tanah sebagai mahar dalam pernikahan.

Selama ini sistem kekerabatan menjadi dasar sehingga dalam proses penyerahan pun biasanya tidak dipertegas mulai dari sertifikat dan surat-surat lainya. Bahwa pemberian tanah sebagai mahar untuk melindungi perempuan setelah menikah, dalam artian tanah sebagai pelindung bagi posisi perempuan dalam keluaganya tidak lagi dipahami oleh masyarakat suku Bugis-Makassar. Bahwa secara psikologis pemberian tanah tersebut sebagai lambang harga diri (harkat dan martabat) dalam menghargai perempuan sehihingga tidak lagi menjadi pengikat atau tanggujawab para suami untuk menghormati dan menjaga ikatan pernikahannya karena Ia merasa tidak kehilangan apa-apa.

Dari uraian di atas dapat dilihat bahwa, adanya pergeseran pemahan, atau adanya ketidaktahuan sebagian besar masyarakat Bugis-Makassar terkait sunrang tanah sebagai mahar dalam sebuah pernikahan yang hanya dianggap atau dinilai ekonomis semata, atau bahkan dianggap sebatas simbolik, hal ini kemudian mengakibatkan banyaknya polemik bahkan sengketa di ranah hukum terkait persoalan tersebut.

serta dimaksudkan untuk dapat mengangkat harkat, martabat dan sekaligus sebagi penekanan identitas diri perempuan ketika terjadi perselisihan / perpisahan perempuan mempunyai hak untuk melanjutkan mengolah tanah tersebut yang telah menjadi haknya sebagai cara untuk melanjutkan hidupnya, sehingga laki-laki tidak begitu mudah untuk meninggalkan keluarganya. Hal ini juga berkaitan dengan siri" atau harga diri keluarga perempuan untuk melepas putrinya, tidak hanya dengan sibatang kala ( membawa dirinya saja) meskipun dinafkahi oleh suami akan tetapi terlebih pada harkat dan nilai seorang anak perempuan yang nantinya akan berdiri sendiri tanpa tergantung pada keluarga lagi. Selain itu mudah-mudahan menjadi bahan referensi bagi kita semua bahwa pemberian mahar tidak lagi dipandang sebagai lambang ekonomis untuk mengagkat status sosial semata.

\section{SARAN}


Agar issu yang mengangkat tentang status perempuan di Bugis-Makassar lebih dikembangkan lagi agar diskriminasi perempuan dalam pernikahan tidak terjadi lagi. Dengan memberikan sosialisasi pada perempuan Bugis-Makassar tentang pemahamannya terhadap pemberian mahar kepadanya lebih tinggi dalam hal melindungi dan menjaga harga dirinya sebgai perempuan yang memiliki harkat/martabat sebagai suku bugis-makassar. Selain itu diharapkan pemerintah dapat membuat peraturan-peraturan yang dapat melindungi hakhak perempuan soal kepemilikan tanah yang telah manjadi hak miliknya agar diatur secara jelas dalam undang-undang sejalan dengan hukum adat yang berlaku dalam masyarakat.

Agar suami-suami tidak mudah melakukan perceraian / menceraikan istrinya kerena pernikakahan merupakan hal yang membtuhkan pengorbanan lahir dan batin yang diikit dalam "Asipakatau” yaitu memanusiakan manusia lain dengan saling menjaga dan menghormati dengan siri" na Passe', dengan perasaan malu melakukan kesalahan atau meninggalkan istri dan anak tanpa tanggunjawab.

\section{DAFTAR PUSTAKA}

Budiman, arif. 1985. Pembagian kerja secara sexsual, Jakarta : Pt Gramedia

Chabot, Henrick Th. 1984. Bonto Ramba sebuah desa Gowa Sulawesi.

Kontrajaningrat. 1987. Masyarakat desa di indonesia, Jakarta :lembaGa penerbit Fak Ekonomi Universitas Indonesia

Ihromi, T. O . 2000, Budaya dan Struktur Sosial yang patriarki. Jakarta : Program Pasca Sarjana UI

Rahim \& Rahman. 1992. Nilai-Nilai Utama Kebudayaan Bugis. Ujungpandang : Universitas hasanuddin Press 